\title{
Electrophoretic Profile of Seminal Plasma Proteins of Specific Fractions of Large White Yorkshire Boar Semen
}

\author{
Malati Naik $^{1}{ }^{*}$, Hiron M. Harshan ${ }^{1}$, K. Promod ${ }^{1}$, C.P. Abdul Azeez ${ }^{1}$, \\ A.P. Usha ${ }^{2}$, C. Sunanda ${ }^{3}$ and C.R. Vishak ${ }^{2}$ \\ ${ }^{1}$ College of Veterinary and Animal Sciences, Pookode, Lakkidi P.O., \\ Wayanad, Kerala - 673 576, India \\ ${ }^{2}$ Director of Farms, KVASU and Professor and Head, Centre for Pig Production and \\ Research, Mannuthy, India \\ ${ }^{3}$ Department of Statistics, CVAS, Pookode, India \\ *Corresponding author
}

\begin{tabular}{|c|c|}
\hline & A B S T R A C T \\
\hline $\begin{array}{l}\text { Ke y w o r d s } \\
\text { Boar semen, SDS- } \\
\text { PAGE, Seminal } \\
\text { plasma protein, } \\
\text { Sperm rich fraction }\end{array}$ & $\begin{array}{l}\text { The objective of the research was to study the protein content and electrophoretic profile } \\
\text { of specific fractions of Large White Yorkshire (LWY) boar semen. Sperm rich fractions } \\
\text { (SRF) of semen were collected from four sexually mature LWY boars as fractions of } 10 \\
\mathrm{~mL} \text { each, by gloved hand method. For analysis, the first } 10 \mathrm{~mL} \text { of the SRF, rest of the SRF } \\
\text { and sperm free fraction (SFF) were collected separately. The protein content of the semen } \\
\text { fractions was assessed and the proteins were subjected to one dimensional discontinuous } \\
\text { sodium dodecyl sulphate polvacrvlamide gel electrophoresis (SDS-PAGE) to assess the }\end{array}$ \\
\hline Article Info & electrophoretic profile. A protein content of $20.71 \pm 2.63 \mathrm{mg} / \mathrm{mL}$ was observed in the first \\
\hline $\begin{array}{l}\text { Accepted: } \\
\text { 12 July } 2019 \\
\text { Available Online: } \\
10 \text { August } 2019\end{array}$ & $\begin{array}{l}10 \mathrm{~mL} \text { of SRF, } 21.77 \pm 1.84 \mathrm{mg} / \mathrm{mL} \text { in the remaining SRF and } 20.52 \pm 2.06 \mathrm{mg} / \mathrm{mL} \text { in the } \\
\text { SFF. An average number of } 13.5 \pm 0.51 \text { bands were observed in first } 10 \mathrm{~mL} \text { of SRF, } 12.92 \\
\pm 0.44 \text { bands in the remaining part of SRF and } 12.78 \pm 0.23 \text { bands in the SFF. The proteins } \\
\text { observed varied in the molecular weight from } 18-244 \mathrm{kDa}, 8-242 \mathrm{kDa} \text { and } 9-248 \mathrm{kDa} \\
\text { in first } 10 \mathrm{~mL} \text { of SRF, remaining SRF and SFF, respectively. }\end{array}$ \\
\hline
\end{tabular}

\section{Introduction}

Artificial insemination (AI) is a well-adopted reproductive technology in the bovine species but the practice of $\mathrm{AI}$ is still gaining momentum in swine industry. In fact, during last decade, use of extended boar semen for AI had increased significantly (Maes et al., 2011). The differences in the fertility rate among the breeding males were not addressed completely by routine semen evaluation parameters. However, attention was also given to other aspects of semen quality as markers of fertility like seminal plasma proteins (Larson and Miller, 2000).

Boar ejaculate consists of several consecutive jets expelled as fractions, with up to three fractions easily identified by their appearance and density. The first fraction is watery being called pre-sperm fraction, the second fraction is called SRF and the semen with free of 
sperms is called SFF, which varied in their biochemical compositions and were influenced by the roles of testis, epididymis and accessory sex glands during ejaculation. The SRF has the highest sperm concentration and contributes around 10-30 per cent to the semen volume, while the post SRF contains protein-rich secretions which contribute remaining 70-90 per cent of the whole semen volume (Saravia, 2008). A variety of proteins in the seminal plasma influence sperm function in the female reproductive tract (Rodriguez-Martinez et al., 2011).

Saravia (2008) observed that certain portions of boar semen withstood cold shock and cryopreservation better than the other portions. Spermatozoa in the first $10 \mathrm{~mL}$ of the SRF were found to be better in preservability than in other portions. The protein composition of these portions and certain biochemical constituents like the bicarbonate differed and were likely responsible for the differences observed in the preservability of the portions. Some of proteins like osteopontin, prostaglandin D synthase, bovine seminal plasma proteins (BSP A1, A2, A3) and heparin-binding proteins have been reported as markers of bull fertility (Moura et al., 2007). The study was hence directed at assessing the protein content and SDS-PAGE profile of the different portions of seminal plasma, namely, the first $10 \mathrm{~mL}$ of SRF, the remaining portion of SRF and the SFF.

\section{Materials and Methods}

\section{Location of the study and collection of semen}

The study was conducted using four adult Large White Yorkshire (LWY) boars maintained at the Centre for Pig Production and Research, Mannuthy, Thrissur, India. The semen was collected by 'gloved hand' method
(Hancock and Hovell, 1959) using dummy sow. The pre sperm fraction was discarded and the SRF and SFF of semen were collected as fractions of $10 \mathrm{~mL}$ each through a Buchner funnel to separate the gel mass. The first 10 $\mathrm{mL}$ of SRF was considered as F1 and the remaining portion of SRF as F2. The ejaculate fractions were supplemented with a protease inhibitor cocktail (Protease Inhibitor Cocktail; Cat No. 539134, Sigma Aldrich, USA) at the rate of $10 \mu \mathrm{l}$ per $\mathrm{mL}$ immediately after collection. The collected semen fractions were immediately transferred to an insulated container and transported to the laboratory for preliminary evaluation. Those samples which had a progressive sperm motility of 70 per cent or above alone were selected for the study, thus a total of 16 ejaculates, four from each boar, were used.

\section{Harvest of seminal plasma and assessment of protein content}

The samples after evaluation were the centrifuged immediately $(2000 \times \mathrm{g}$ for $15 \mathrm{~min}$ at room temperature) to separate seminal plasma and sperm. The supernatant plasma was collected and re-centrifuged $(10,000 \times \mathrm{g}$ for $30 \mathrm{~min}$ at $5^{\circ} \mathrm{C}$ ) to further clarify the plasma from cell debris and the harvested plasma was stored in Eppendorf tubes at $70^{\circ} \mathrm{C}$ until analysis. Protein content of the seminal plasma of the fractions was estimated as per Lowry et al., (1951) employing protein estimation kits (GeNei ${ }^{\mathrm{TM}}$, Merck, Product No 2601800011730) as per the manufacturer's instructions.

\section{SDS-PAGE analysis}

The protein profile of seminal plasma fractions was assessed by SDS-PAGE, which was run as per the method described by Laemmli (1970) with slight modifications in a Mini - PROTEAN Tetra Electrophoresis System (Bio-Rad, USA). The separating gel 
had strength of 10 per cent and a thickness of $0.75 \mathrm{~mm}$. Fifty $\mu \mathrm{g}$ of sample was loaded in each well of the polymerized gel and a molecular weight (MW) protein marker (Perfect Protein Marker $^{\mathrm{TM}}$ wide range $\mathrm{MW}$ $15-150 \mathrm{kDa}$ ) was run in each gel for analysis. Electrophoresis was carried out in constant voltage mode at $80 \mathrm{~V}$ till the dye front entered the stacking gel, thereafter electrophoresis was carried out at $120 \mathrm{~V}$ till the dye front reached end of the gel. The current was discontinued and the gel was removed from the glass plate. The stacking gel was snipped off and the separating gel was fixed in fixing solution for one hour. The gels were stained using Coomassie brilliant blue R-250 for six hours followed by de-staining for two or three times. The imaging of the gel was done in Chemi Doc ${ }^{\mathrm{TM}}$ MP Imaging System (Bio-Rad, USA) and analysis with Gel analyzer 2010 software.

\section{Results and Discussion}

The mean total protein of F1 was found to be $20.71 \pm 2.63 \mathrm{mg} / \mathrm{mL}$. In F2 and SFF, mean total protein was found to be $21.77 \pm 1.84$ and $20.52 \pm 2.06 \mathrm{mg} / \mathrm{mL}$, respectively. Within fractions, the total protein varied between boars. In F1, it varied from a mean of $14.22 \pm$ 1.45 to $30.37 \pm 7.38 \mathrm{mg} / \mathrm{mL}$, in $\mathrm{F} 2$ from 15.32 \pm 4.84 to $26.88 \pm 2.32$ and in SFF from 15.16 \pm 2.11 to $25.36 \pm 5.74 \mathrm{mg} / \mathrm{mL}$ (Table 1 ).
The SDS-PAGE electrophoretic profile revealed $13.5 \pm 0.51$ bands in $\mathrm{F} 1$ ranging from $12-18$ between ejaculates, $12.92 \pm 0.44$ in F2 ranging from $10-16$ between ejaculates and $12.78 \pm 0.23$ in SFF ranging from $11-14$ between ejaculates (Table 2). The protein bands in F1, F2 and SFF had a MW ranging from $18-244 \mathrm{kDa}, 8-242 \mathrm{kDa}$ and $9-248 \mathrm{kDa}$, respectively. Variations in the presence of bands were observed both between boars and between collections of the same boar. A protein band with a MW of $203.66 \pm 0.33 \mathrm{kDa}$ and $126.0 \pm 0.0 \mathrm{kDa}$ was absent in F2 and SFF but present in F1 with an incidence of $21.43 \%$ and $7.14 \%$ per cent, respectively. The band with MW of $158.0 \pm$ $0.0 \mathrm{kDa}$ was present in $\mathrm{SFF}$ alone, with an incidence of 14.29 per cent, while the band with a MW of $119.4 \pm 0.26$ was absent in SFF but present in F1 and F2 with an incidence of 35.71 and 15.38 per cent, respectively. The band with MW of $9 \pm 0.58 \mathrm{kDa}$ was absent in F1 but present in F2 and SFF with an incidence of 15.38 and 7.14 per cent, respectively.

When considering all the fractions of the ejaculate, it was noticed that the protein bands with molecular weight ranging from $9.0 \pm$ 0.58 to $21.98 \pm 0.14 \mathrm{kDa}$ and $63.63 \pm 0.34$ to $88.0 \pm 0.0 \mathrm{kDa}$ were the prominent bands.

Table.1 Total protein content of semen fractions in Large white Yorkshire boar (in $\mathrm{mg} / \mathrm{mL}$ )

\begin{tabular}{|c|c|c|c|}
\hline Animal & F 1 & F 2 & SFF \\
\hline Boar $1(n=4)$ & $14.22 \pm 1.45$ & $18.63 \pm 1.36$ & $15.16 \pm 2.11$ \\
\hline Boar $2(n=4)$ & $21.25 \pm 5.59$ & $15.32 \pm 4.84$ & $18.80 \pm 4.85$ \\
\hline Boar $3(n=4)$ & $17.01 \pm 0.94$ & $26.88 \pm 2.32$ & $25.36 \pm 5.74$ \\
\hline Boar $4(n=4)$ & $30.37 \pm 7.38$ & $26.26 \pm 2.25$ & $22.76 \pm 2.18$ \\
\hline Overall $(n=16)$ & $20.71 \pm 2.63$ & $21.77 \pm 1.84$ & $20.52 \pm 2.06$ \\
\hline
\end{tabular}

F 1: first $10 \mathrm{~mL}$ of SRF (highest sperm concentration)

F2: rest of the SRF

ns - non significant 
Table.2 Number of protein bands and Molecular weight in semen fractions in Large white Yorkshire boar as assessed by one dimensional SDS-PAGE)

\begin{tabular}{|c|c|c|c|}
\hline Animal & F 1 & F 2 & SFF \\
\hline Boar $1(n=4)$ & $13.25 \pm 0.95$ & $13.67 \pm 1.86$ & $12.75 \pm 0.63$ \\
\hline Boar $2(n=3)$ & $15.67 \pm 1.45$ & $13.67 \pm 0.33$ & $13.33 \pm 0.33$ \\
\hline Boar $3(n=4)$ & $12.00 \pm 0.00$ & $11.75 \pm 0.25$ & $12.25 \pm 0.25$ \\
\hline Boar $4(n=3)$ & $13.67 \pm 0.33$ & $13.00 \pm 0.00$ & $13.00 \pm 0.58$ \\
\hline Overall $(n=14)$ & $13.5 \pm 0.51$ & $12.92 \pm 0.44$ & $12.78 \pm 0.23$ \\
\hline M Wt. Range & $18-244 \mathrm{kDa}$ & $8-242 \mathrm{kDa}$ & $9-248 \mathrm{kDa}$ \\
\hline \multicolumn{4}{|c|}{ F value (p value) for between fractions $=0.856(0.433)^{\mathrm{ns}}$} \\
\hline
\end{tabular}

F1: first $10 \mathrm{~mL}$ of SRF (highest sperm concentration)

F2: rest of the SRF

ns - non significant

Though no significant differences were observed between protein content of fractions in the present study, previous reports have indicated a lower protein concentration in the sperm peak fraction (F1) than the other portions of SRF (Rodriguez-Martinez et al., 2008; Novak et al., 2010). They ascribed a negative correlation between the total protein and sperm concentration of ejaculate. The reasons for the low protein content of F1 was explained to the F1 containing more of prostatic secretions with lower concentrations of PSP-I than the SRF and to the high concentration of sperm in F1, which would retain a higher proportion of proteins in sperm membrane thus reducing the residual amount of total protein in seminal plasma. However, Garcia et al., (2009) reported lower levels of both total protein $(15.37 \mathrm{mg} / \mathrm{mL})$, PSP-I and PSP-II heterodimer $(1.8 \mathrm{mg} / \mathrm{mL})$ and also low amount of heparin binding protein in SRF.

Rodrigeuz Martinez et al., (2005) found that the first jets of SRF had an average total protein of $7.0 \pm 1.3 \mathrm{~g} / \mathrm{L}$ and next portion of SRF had $32.4 \pm 12.7 \mathrm{~g} / \mathrm{L}$, there was a significant difference between sperm rich fractions in their protein content. Further analysis by reverse phase HPLC and MALDITOF mass spectrometry also showed different protein composition in SRF.
Karunakaran et al., (2015) had recorded 11 protein bands with MW ranging from 14 to $200 \mathrm{kDa}$ in whole seminal plasma of Large white Yorkshire boars and also recorded the high intensity protein bands with molecular weight of 116-200 kDa in SRF of LWY boar semen. Out of eleven protein bands, five protein bands were common in eight boars, had MW of 116-200 kDa, 66-97 kDa, 55-66 $\mathrm{kDa}$ and $45-55 \mathrm{kDa}$. Protein bands of MW 97-116 kDa, 36-45 kDa, 29-36 kDa, 20-29 $\mathrm{kDa}$ and $14-20 \mathrm{kDa}$ were observed only in $50 \%, 12.5 \%, 62.5 \%, 25 \%$ and $25 \%$ of the boars respectively.

Novak et al., (2010) used western blotting technique to identify the boar seminal proteins and identified certain proteins like OPN-9 (9 kDa), OPN-12 (12 kDa), AWN-1 (14 kDa) and Osteopontin -70 (70 kDa).

Some of these proteins were positively correlated with fertility. Total protein content of the seminal plasma had an inverse relationship with both zona pellucida penetration rate and number of sperm penetrating the zona, indicating that higher the total protein content higher would be the decapacitation effect in turn decline in fertilization rate in vitro (Novak et al., 2010). 
Zasiadczyk et al., (2015) noted that seasonal variations on SDS-PAGE profiles were associated with lot of low and high-molecular weight protein fractions, especially during the autumn-winter period and suggested that the noticeable decline in the quality of the ejaculated fractions during the spring-summer period was due to impaired reproductive function.

Monomeric and aggregated forms of proteins secreted by the accessory sexual glands binds to the sperm surface during ejaculation that will further cause extensive remodelling of the sperm membrane (Manaskova et al., 2003). These changes brought about post testicular sperm maturation, ability to fertilize an egg and influence essential steps in the fertilization process. After ejaculation, these monomeric forms of AWN-1 and AQN-3 spermadhesins formed first coating over the sperm plasma membrane and thereafter, the spermatozoa would be coated by a layer of aggregated spermadhesins serving stabilizing factors from premature acrosome reaction (Dostalova et al., 1995, Topfer-Peterson et al., 1998). It has been suggested that binding of proteins over the sperm head would cause slight removal of cholesterol which is considered to be primary step of capacitation and further sperm would come in contact with high density lipoproteins (HDLs) and Glycosamine glycons (GAGs) of the oviductal fluid that removed protein from the sperm membrane and at the same time induced second cholesterol efflux subsequently remodel the sperm membrane (Manjunath and Therien, 2002; Manjunath et al., 2007) this phenomenon associated with capacitation.

As a part of fertilization process, seminal plasma proteins play important role in sperm capacitation, establishment of the oviductal sperm reservoirs, gamete recognition, primary and secondary binding of the sperm to the ovum, acrosome reaction of sperm, penetration of the sperm through the zona pellucida of the ovum and fusion of sperm and egg (Topfer-petersen et al., 2005) and also preserve membrane integrity by exerting inhibiting effects on the mitochondrial activity and metabolism to conserve energy required until fertilization, to reduce the reactive oxygen species production and lipid peroxidation of sperm membrane (Schoneck et al., 1996). The future research should thus focus on identifying these factors in boar seminal plasma and their interaction with the sperm.

\section{Acknowledgement}

The authors acknowledge the Deans of college of Veterinary and Animal Sciences, Mannuthy and Pookode and Professor, Central instrumentation laboratory, Mannuthy for the facilities provided for the conduct of the research. The first author acknowledges the fellowship provided by the Kerala Veterinary and Animal Sciences University for the duration of academic and research programme.

\section{References}

Dostalova, Z., Calvete, J. J. and Topfer-Petersen, E. 1995. Interaction of non- aggregated boar AWN-1 and AQN-3 with phospholipid matrices. A model for coating of spermadhesins to the sperm surface. Biol. Chem. Hoppe. Seyler. 376(4), 237-242.

Garcia, E. M., Calvete, J. J, Sanz, L, Roca, J, Martinez, E. A. and Vazquez, J. M. 2009. Distinct effects of boar seminal plasma fractions exhibiting different protein profiles on the functionality of highly diluted boar spermatozoa. Reprod. Domest. Anim. 44(2), 200-205.

Hancock, J., and Hovell, G. 1959. The collection of boar semen. Vet. Rec. 71(664): 664-665.

Karunakaran, M., Ratnakaran, U, Naik, P. K. and Chakurkar, E. B. 2015. Electrophoretic profile of boar seminal proteins. J. Appl. Anim. Res. 44(1), 403-405. 
Larson, J. L., and Miller, D. J. 2000. Can relative spermatozoal galactosyl transferase activity be predictive of dairy bull fertility? J. Dairy Sci. 83(11): 2473-2479.

Laemmli, U. K., 1970. Cleavage of structural proteins during the assembly of the head of bacteriophage T4. Nature. 227(5259), 680-685.

Lowry, O. H., Rosenbrough, N. J, Farr, A. and Randall, R. J. 1951. Protein measurement with the Folin phenol reagent. J. Biol. Chem. 193(), 265-275.

Maes, D., Lopez Rodriguez, A, Rijisselaere, T, Vyt, P. and Van Soom, A. 2011. Artificial insemination in pigs. In: Manafi (Ed), Artificial insemination in farm animals. In Tech,pp. 7994.

Manaskova, P., Balinova, P, Kraus, M, Ticha, M. and Jonakova, V. 2003. Mutual interactions of boar seminal plasma proteins studied by immunological and chromatographic methods. Am. J. Reprod. Immunol. 50(5), 399-410.

Manjunath, P., Bergeron, A, Lefebvre, J. and Fan, J. 2007. Seminal plasma proteins: functions and interaction with protective agents during semen preservation. Soc. Reprod. Fertil. Suppl. 65, 217-228.

Manjunath, P. and Therien, I. 2002. Role of seminal plasma phospholipid-binding proteins in sperm membrane lipid modification that occurs during capacitation. J. Reprod. Immunol. 53(1-2): 109119.

Moura, A. A., Chapman, D. A, Koc, H. and Killian, G. J. 2007. A comprehensive proteomic analysis of cauda epididymal fluid and identification of proteins associated with fertility scores of mature dairy bulls. J. Androl. 98(3-4), 71-77.

Novak, S., Ruiz-Sanchez, A, Dixon, W. T, Foxcroft, G. R. and Dyck, M. K. 2010. Seminal plasma proteins as potential markers of relative fertility in boars. J. Androl. 31(2), 188-200.

Rodriguez-Martínez, H., Saravia, F, Wallgren, M, Tienthai, P, Johannisson, A, Vazquez, J., Martinez, E, Roca, J, Sanz, L. and Calvete, J. J. 2005. Boar spermatozoa in the oviduct. Theriogenology, 63(2), 514-535.

Rodriguez-Martinez, H., Saravia, F, Wallgren, M, Roca, J. and Pena, F. J. 2008. Influence of seminal plasma on the kinematics of boar spermatozoaduring freezing. Theriogenology. 70(8), 1242-1250.

Rodriguez-Martinez, H., Kvist, U, Ernerudh, J, Sanz, L. and Calvete, J. J. 2011. Seminal plasma proteins: What role do they play? Am. J. Reprod. Immunol. 66(1), 11-22.

Saravia, F., 2008. Cryopreservation of boar semen:impact of the use of specific ejaculate portions, concentrated packaging, and simplified freezing procedures on sperm cryosurvival and potential fertilising capacity. Doctoral thesis. Swedish University of Agricultural Sciences, Uppsala.

Schoneck, C., Braun, J. and Einspanier, R. 1996. Sperm viability is influenced in vitro by the bovine seminal protein aSFP: effects on motility, mitochondrial activity and lipid peroxidation. Theriogenology. 45(3), 633-642.

Topfer-Petersen, E., Romero, A., Varela, P. F., Ekhlasi-Hundrieser, M., Dostalova, Z., Sanz, L. and Calvete, J. J. 1998. Spermadhesins: a new protein family. Facts, hypotheses and perspectives. Andrologia. 30(4-5), 217-224.

Topfer-Petersen, E., Ekhlasi-Hundrieser, M, Kirchhoff, C, Leeb, T. and Sieme, H. 2005. The role of stallion seminal proteins in fertilisation. Anim. Reprod. Sci. 89(1-4), 159-170.

Zasiadczyk, L., Fraser, L, Kordan, W. and Wasilewska, K. 2015. Individual and seasonal variations in the quality of fractionated boar ejaculates. Theriogenology. 83(8), 1287-303.

\section{How to cite this article:}

Malati Naik, Hiron M. Harshan, K. Promod, C.P. Abdul Azeez, A.P. Usha, C. Sunanda and Vishak, C.R. 2019. Electrophoretic Profile of Seminal Plasma Proteins of Specific Fractions of Large White Yorkshire Boar Semen. Int.J.Curr.Microbiol.App.Sci. 8(08): 1669-1674. doi: https://doi.org/10.20546/ijcmas.2019.808.197 